\title{
INSTYTUCJE POŚREDNICTWA PRACY \\ - REGULACJE PRAWNE OKRESU MIĘDZYWOJENNEGO W POLSCE
}

\section{WPROWADZENIE}

Analizując literaturę przedmiotu w sferze dotyczącej instrumentów walki z bezrobociem w Polsce okresu międzywojennego, w tym również stanowisko Ministerstwa Pracy i Opieki Społecznej, dojdziemy do jednego wspólnego wniosku: dominowało wówczas przeświadczenie, że jedynie należycie zorganizowane instytucje państwowego pośrednictwa pracy (z akcentem na słowo: „państwowego") stanowią najefektywniejszy i bezpośredni środek zaradczy skutecznego przeciwdziałania bezrobociu, które, jakkolwiek było zjawiskiem niepożądanym, to zarazem pozostawało stałym elementem rzeczywistości społeczno-gospodarczej Polski okresu międzywojennego ${ }^{1}$.

Analiza skali i struktury bezrobocia w Polsce międzywojennej nie jest zadaniem latwym, a przedstawiane wskaźniki tak w literaturze, jak i w oficjalnych raportach urzędów pośrednictwa pracy, jak podaje K. Mlonek, nie zawsze odzwierciedlały rzeczywistą skalę bezrobocia, gdyż proces rejestracji nie obejmował wszystkich osób poszukujących zatrudnienia. Same osoby bezrobotne nie zawsze były zainteresowane zgłaszaniem swojego statusu - wykazywały wzmożoną aktywność rejestracyjną jedynie w okresach, gdy możliwe było pozyskanie zatrudnienia za

Dr hab. Sebastian KwiEcień - adiunkt w Katedrze Prawa Pracy i Ubezpieczeń Społecznych, Instytut Nauk Prawnych, Wydział Prawa, Prawa Kanonicznego i Administracji, Katolicki Uniwersytet Lubelski Jana Pawła II, Al. Racławickie 14, 20-950 Lublin; e-mail: skwiecien@kul.pl; https://orcid. org/0000-0003-4858-794X

${ }^{1}$ Pamiętać należy, że stopa bezrobocia w swoich szczytowych okresach sięgała ponad $30 \%$, zob. K. MLoneK, Bezrobocie w Polsce w XX wieku w świetle badań, Warszawa: Krajowy Urząd Pracy 1999, s. 27; por także: Pośrednictwo pracy w Polsce, Warszawa: Ministerstwo Pracy i Opieki Społecznej 1921, [w:] http://bc.radom.pl/dlibra/doccontent?id=25188 [dostęp: 12.11.2019], s. 7. 
pośrednictwem urzędu pracy w ramach zlecanych przez państwo lub samorząd prac publicznych bądź przez rolników i przedsiębiorców robót sezonowych ${ }^{2}$. W podobnym tonie wypowiada się E. Stańczyk, która jasno stwierdza, że najwiarygodniejszym źródłem informacji o bezrobociu były nie dane urzędów pośrednictwa pracy, a wyniki powszechnych spisów ludności. Co jednak ciekawe, formularze spisowe nie przewidywały możliwości wpisania informacji o byciu osobą bezrobotną; o swoim statusie, osoby informowały poprzez dokonanie wzmianki na przedmiotowym formularzu ${ }^{3}$. Przykładowo: według danych urzędowych z $1931 \mathrm{r}$. bezrobotnych poza rolnictwem było 312,5 tys. osób, tymczasem według spisu ludności liczba ta wynosiła aż 681,4 tys. $^{4}$

Niewątpliwie godziwa praca odgrywa doniosłe znaczenie w życiu społecznym człowieka. Państwo, tworząc kompleksowy aparat pomocy osobom bezrobotnych, w tym również w sferze pośrednictwa pracy, w pierwszej kolejności powinno kierować się zasadą ochrony godności pracownika i stworzyć taki system pomocy, który będzie sprawnie reagował na zmiennym i skomplikowanym rynku pracy. Potrzebny był zatem aparat świadomej polityki zatrudnienia, który będzie oceniał sytuację, rozumiał strony zainteresowane jego usługami, aktywnie kreował rynek pracy i eliminował sytuacje zagrażające polityce zatrudnienia.

Obowiązek aktywnego kreowania polityki zatrudnienia wynikał również wprost z przepisu art. 102 Konstytucji marcowej ${ }^{5}$, który ustanawiał prawo każdego obywatela do opieki państwa nad jego pracą, a w razie jej braku - prawo do zasiłku. Z normy tej wywodzono zarówno obowiązek opieki socjalnej nad bezrobotnymi, jak i pomoc państwa w znalezieniu zatrudnienia. Niewątpliwie sposób, w jaki państwo obejmuje ochroną swoich obywateli, w tym osób bezrobotnych, które z uwagi na sytuację gospodarczą państwa lub społeczną borykają się z problemem bezrobocia lub niestałością zatrudnienia, jest miarą rozwoju ustawodawstwa socjalnego danego kraju.

W 1921 r. w przywołanej już publikacji Ministerstwa Pracy i Opieki Społecznej wskazano, w mojej ocenie bardzo słuszne i zasadne, warunki, jakim powinien odpowiadać państwowy system pośrednictwa pracy:

- biura pośrednictwa pracy powinny tworzyć gęstą sieć, tak aby osoba poszukująca pracy (oraz pracodawca) miała szybki i sprawny do niej dostęp;

\footnotetext{
${ }^{2}$ Tamże, s. 22-23.

${ }^{3}$ E. STAŃCZYK, Środowisko pracy w II Rzeczypospolitej, „Acta Universitatis Wratislaviensis. Przegląd Prawa i Administracji” 77 (2008), s. 293-311.

${ }^{4}$ MloneK, Bezrobocie w Polsce, s. 27.

${ }^{5}$ Ustawa z dnia 17 marca 1921 r. - Konstytucja Rzeczypospolitej Polskiej, Dz. U. Nr 44, poz. 267.
} 
- każde biuro pośrednictwa pracy winno działać na określonym obszarze oraz szybko reagować na zmiany tam zachodzące, aby celowo i wyczerpująco informować swoich klientów o warunkach zatrudnienia na danym terenie;

- wszystkie biura zobowiązane są do ścisłej współpracy;

- w przypadku poszukującego pracy zakazane jest pobieranie przez biuro opłat;

- rynek pośrednictwa pracy winien być ściśle powiązany z organizacjami zawodowymi pracodawców i pracowników ${ }^{6}$.

Z przedmiotowej publikacji wynika jednak wskazany już we wstępie zasadniczy wniosek, który odcisnął swoje piętno na całym budowanym po 1918 r. systemie pośrednictwa pracy w Polsce. Mianowicie, najbardziej cenioną i pożądaną formą pośrednictwa pracy była ta o charakterze państwowym. Według Ministerstwa tylko państwo posiadało instrumenty, dzięki którym mogło aktywnie ingerować w rynek pracy. Pozostałe dwie formy funkcjonujące w Polsce, a odziedziczone po zaborcach, tj. społeczne i zawodowe pośrednictwo pracy, miały jedynie uzupełniać system państwowego pośrednictwa ${ }^{7}$. Formy te, jakkolwiek utrzymane przez cały okres międzywojenny, były jedynie akceptowane przez państwo, jednak niepożądane.

Regulacje prawne, które pozwoliły zbudować system pośrednictwa pracy, wprowadzane były przez pięć lat. $\mathrm{W}$ tym czasie rozstrzygnięto, jaką rolę będą odgrywały społeczne biura pracy oraz czy nadal dopuszczalne będzie wykonywanie działalności gospodarczej w sferze zarobkowego pośrednictwa pracy.

Ta druga kwestia budziła najwięcej kontrowersji. Według założeń Ministerstwa Pracy i Opieki Społecznej z uwagi na fakt, że działalność gospodarcza nastawiona była na zysk, a pośrednictwo pracy to niewątpliwie sfera społecznie wrażliwa, musi zostać ona poddana nadzorowi państwa i objęta rygorem koncesyjnym, co też zresztą uczyniono. Ustawodawca uznał, że ta forma pomocy bezrobotnym w sposób negatywny wpływa na regulacje polityki zatrudnienia i wprowadza swoisty chaos w systemie polityki socjalnej państwa, mimo to zdecydował się ją utrzymać. Było to o tyle istotne stanowisko, że ta sfera aktywności gospodarczej, jakkolwiek

\footnotetext{
${ }^{6}$ Pośrednictwo pracy, s. 7-8.

${ }^{7}$ Zasadą było, że państwowe pośrednictwo pracy tworzono na bazie już istniejących biur pośrednictwa pracy powołanych jeszcze przez zaborców lub w okresie okupacji. Były to głównie małe społeczne biura, powoływane przez związki zawodowe celem łagodzenia negatywnych skutków wzrostu bezrobocia. Dodatkowo w Galicji, by ułatwić osobom zdemobilizowanym znalezienie pracy, biura, powoływane również przez władze wojskowe, weszły następnie do systemu państwowego pośrednictwa pracy. Zob. Sprawozdanie z działalności biura pośrednictwa pracy od 17 grudnia 1914 roku do 1 lipca 1915 roku, Łódź [b.w.] 1915, [w:] https://polona.pl/item/sprawozdanie-z-dzialalnosci-biura-posrednictwa-pracy-od-17-xii-1914-r-do-1-vii-1915-r,NzQwNzg4MzE/2/\#info:metadata [dostęp: 17.11.2019] oraz M. PrzeniosŁo, Problemy społeczne Galicji Zachodniej w poczatkach II Rzeczypospolitej (wybrane zagadnienia), „Studia z Historii Społeczno-Gospodarczej XIX i XX wieku” 12 (2013), s. 93-94.
} 
znana w całej Europie, od początku XX w. ulegała znacznemu ograniczaniu lub nawet likwidacji jako działalność gospodarcza społecznie niepożądana. Podejście to mogło być efektem wytycznych Konferencji Generalnej Międzynarodowej Organizacji Pracy ${ }^{8}$ postulującej, aby zakazano funkcjonowania zarobkowych biur pośrednictwa pracy jako szkodliwych dla państwowego systemu pośrednictwa ${ }^{9}$.

Społeczne biura pośrednictwa pracy, w przeciwieństwie do tych prowadzonych zawodowo, były akceptowane przez państwo, o ile prowadziły je organizacje zawodowe, co, z uwagi na znajomość branżowego rynku pracy, dawało gwarancje najlepszego powiązania pracownika z pracodawcą. Były one przejawem aktywności samych zainteresowanych, co z kolei było zgodne z założeniami budowy systemu pośrednictwa pracy $^{10}$.

\section{PAŃSTWOWE POŚREDNICTWO PRACY}

Na mocy dekretu Naczelnika Państwa z dnia 27 stycznia 1919 r. o organizacji państwowych urzędów pośrednictwa pracy i opieki na wychodźcami ${ }^{11}$ powołano państwowe urzędy pośrednictwa pracy i opieki nad wychodźcami, które podlegały bezpośrednio Ministerstwu Pracy i Opieki Społecznej ${ }^{12}$, a których działalność od samego początku oparto na zasadzie: równości, jawności, bezstronności, bezpłatności i fachowości ${ }^{13}$.

Wydanie przedmiotowego dekretu było społecznie pożądane i eliminowało z polskiego systemu prawnego rozwiązania państw zaborczych, które nie były

\footnotetext{
${ }^{8}$ Powołana do życia 28 czerwca 1919 r. na paryskiej konferencji pokojowej jako autonomiczna organizacja stowarzyszona z Ligą Narodów. Polska ratyfikowała 35 konwencji, w tym konwencję nr 9, dotyczącą pośrednictwa pracy dla marynarzy z 1920 r., Dz. U. z 1925 r. Nr 54, poz. 374. Więcej na ten temat: H. Sterling, Międzynarodowa Organizacja Pracy i jej działalność, Warszawa: Księgarnia Robotnicza 1928; M. Bornstein-ŁychowsKa, Międzynarodowa Organizacja Pracy. Praca i organizacja, Warszawa: Ministerstwo Pracy i Opieki Społecznej 1928; Międzynarodowa Organizacja Pracy, a prawa kobiet, Warszawa [b.w.] 1930 oraz H. Zasztowt-SukiennickA, Międzynarodowa Organizacja Pracy, Warszawa-Wilno: L. Chomiński 1929.

${ }^{9}$ Pośrednictwo pracy, s. 9.

${ }^{10}$ Tamże, s. 10-11.

${ }^{11}$ Dz. P.P. Nr 11, poz. 127.

${ }^{12}$ Faktyczny nadzór nad działalnością państwowych biur pośrednictwa pracy sprawował wojewoda, co wynikało wprost z art. 27 pkt 4 rozporządzenia Prezydenta Rzeczypospolitej z dnia 19 stycznia 1928 r. o organizacji i zakresie działania władz administracji ogólnej, Dz. U. Nr 11, poz. 86. Zob. T. KozŁowsKi, Inspekcja pracy w Polsce w latach 1919-1939. Organizacja i działalność, Warszawa: Państwowa Inspekcja Pracy 2019, s. 54-55 oraz S. JANKowski, Nowa organizacja inspekcji pracy, „Praca i Opieka Społeczna” 4 (1927), s. 24-33.

${ }^{13}$ H.Ł.O.W.S., Państwowe pośrednictwo pracy w Polsce i jego reformy, „Praca i Opieka Społeczna" 3 (1933), s. 221.
} 
jednorodne, co utrudniało kontrolę ich działalności, ale przede wszystkim realizację powierzonych zadań. Dekret z 1919 r. obowiązywał w pierwszej kolejności na terenie byłego Królestwa Polskiego ${ }^{14}$. W następnych latach rozciągano zakres jego obowiązywania na tereny województw wschodnich ${ }^{15}$ oraz ziem byłego zaboru austriackiego, gdzie nie funkcjonował przed wojną system publicznych biur pośrednictwa pracy - istniały tam jedynie biura zawodowe lub społeczne ${ }^{16}$. Odmiennie sytuacja kształtowała się w byłej dzielnicy pruskiej, gdzie utrzymano biura pośrednictwa pracy, lecz poddano je pod bezpośredni nadzór ministerstwa tej dzielnicy ${ }^{17}$.

Zgodnie z postanowieniami dekretu z 1919 r. urzędy pośrednictwa pracy powoływano każdorazowo na mocy decyzji Ministra Pracy i Opieki Społecznej w miastach powiatowych, w miejscowościach przygranicznych oraz w pozostałych celem ułatwienia bezrobotnym znalezienia pracy oraz sprawowania opieki nad emigrantami (art. 1) ${ }^{18}$.

Ustawodawca precyzyjnie określił zadania postawione przed państwowymi urzędami pośrednictwa pracy. Należały do nich:

- pośrednictwo pracy dla wszystkich kategorii pracowników poszukujących pracy zarobkowej zarówno w kraju, jak i zagranicą;

- doradztwo w zakresie wyboru oraz zmiany pracy;

- udzielanie informacji w zakresie zasad zatrudnienia i warunków pracy oraz przekazywanie podstawowych informacji celem zapewnienia poszukującym pracy bezpieczeństwa;

${ }^{14}$ W byłym Królestwie Polskim już w 1918 r. utworzono urzędy pośrednictwa pracy podległe ówczesnej Sekcji Pośrednictwa Pracy Ministerstwa Pracy i Opieki Społecznej. Wspomnieć należy, że w celu łagodzenia społecznych skutków bezrobocia już w grudniu tego roku powołano Komitety Niesienia Pomocy Bezrobotnym, których działalność polegała na udzielaniu potrzebującym zapomóg pieniężnych lub darowizn żywnościowych, mających jednak charakter doraźny. Rozporządzenie Ministra Pracy i Opieki Społecznej z dnia 12 grudnia 1919 r. w przedmiocie likwidacji Komitetów niesienia pomocy dla bezrobotnych i powołania do życia Powiatowych Komisji Pomocy dla bezrobotnych, Dz. U. z 1920 r. Nr 4, poz. 19.

${ }^{15}$ Rozporządzenie Rady Ministrów z dnia 20 czerwca 1921 r. w przedmiocie rozciągnięcia mocy obowiązującej dekretu z dnia 27 stycznia 1919 r. o organizacji państwowych urzędów pośrednictwa pracy i opieki nad wychodźcami na województwa nowogródzkie, poleskie i wołyńskie oraz na powiaty grodzieński, wołkowyski i białowieski województwa białostockiego, Dz. U. Nr 60, poz. 378

${ }^{16}$ Pośrednictwo pracy, s. 14.

${ }^{17}$ Rozporządzenia Ministra b. Dzielnicy Pruskiej z 14 października 1921 r. o Państwowych urzędach pośrednictwa pracy, Dz. U. Nr 93, poz. 687, zmienione rozporządzeniem ministra Pracy i Opieki Społecznej z dnia 15 lutego 1923 r., Dz. U. Nr 27, poz. 162.

${ }^{18}$ Szeroko o polityce emigracyjnej zob. P. Fiktus, Ochrona prawna emigrantów $w$ latach 1918-1927 w II RP, „Wrocławskie Studia Erazmiańskie. Zeszyty Studenckie” 1 (2008), s. 109-123; M. Szawleski, Kwestja emigracji w Polsce, Warszawa: Polskie Towarzystwo Emigracyjne 1927 oraz A. KICINGER, Polityka emigracyjna II Rzeczpospolitej, „Central European Forum for Migration Research" 4 (2005), s. 1-81. 
- popieranie reemigracji, ochrona emigrantów w granicach kraju;

- zbieranie i zestawianie danych statystycznych na temat rynku pracy ${ }^{19}$;

- pozostałe czynności wskazane przez ustawodawcę.

Państwowe urzędy, powołane, by wyeliminować z rynku niesolidne przedsiębiorstwa prywatne, posiadały faktyczny monopol w zakresie rejestracji i kierowania do pracy osób powracających z innych państw, a także kierowania do robót publicznych.

Roboty publiczne były tym instrumentem, poprzez który państwo inicjowało zatrudnienie większej liczby bezrobotnych, jednocześnie pozytywnie wpływając na dłuższe ożywienie gospodarcze, gdyż inicjowanie robót powiązane było z szerokimi akcjami kredytowymi, pobudzającymi wzrost gospodarczy; niestety, inicjatywa ta zagospodarowywała jedynie bezrobotnych niskowykwalifikowanych ${ }^{20}$.

Artykuł 3 dekretu stanowił fundamentalną zasadę funkcjonowania państwowego systemu pośrednictwa pracy: wszystkie usługi świadczone przez państwowe biura na rzecz osób poszukujących pracy były bezpłatne. Jedynie pracodawcy zobowiązani byli do ponoszenia opłat za usługi świadczone na ich rzecz. W praktyce opłata ta ograniczała się jedynie do zwrotu kosztów kancelaryjnych, które obciążyły urząd pracy w związku ze świadczonymi usługami (koszt druków, formularzy, opłat kancelaryjnych $)^{21}$. Wojewoda na wniosek pracodawcy mógł zwolnić go z obowiązku zwrotu kosztów kancelaryjnych, jeżeli zatrudnienie pracownika lub pracowników związane było z realizacją celu zmniejszenia bezrobocia na danym obszarze.

Państwowe urzędy pośrednictwa pracy zobowiązane były przyjąć każde zgłoszenie o wolnym miejscu pracy ${ }^{22}$. Sposób ewidencjonowania zgłoszeń był bardzo sformalizowany ${ }^{23}$. Problem ten został wyeksponowany przez przedstawicieli zarobkowych biur pośrednictwa pracy w zgłoszonej przez nich petycji do Senatu

${ }^{19}$ Urzędy pracy sporządzały tygodniowe i miesięczne raporty z rynku pracy - w tym celu wysyłano do Ministerstwa Pracy i Opieki Społecznej stosowne raporty z informacją statystyczną i krótkim opisem stanu zatrudnienia za dany okres sprawozdawczy. Jednocześnie wskazywano tendencje w zatrudnieniu na następny okres sprawozdawczy. Zob. Archiwum Państwowe w Lublinie, Zespół Lubelski Urząd Wojewódzki [dalej cyt.: APL, ZLUW], sygn. 35/403/0/2/324 oraz 35/403/0/2/325.

${ }^{20} \mathrm{~W} 1925$ r. liczba zatrudnionych robotników w ramach robót publicznych wyniosła 174957 , a już w 1928 r. liczba ta wzrosła do 394 536. B. OKulicz, Roboty publiczne w świetle działalności Ministerstwa Opieki Społecznej, „Praca i Opieka Społeczna”3 (1933), s. 216-217.

${ }^{21} \S 1$ rozporządzenia Ministra Pracy i Opieki Społecznej z dnia 3 marca 1923 r. w przedmiocie zwrotu kosztów kancelaryjnych przez pracodawców, którzy przyjęli do pracy pracowników poleconych przez Państwowe Urzędy Pośrednictwa Pracy, Dz. U. Nr 28, poz. 176. Przedmiotowe rozporządzenie uchylało poprzedzające je pochodzące z dnia 12 października 1922 r., Dz. U. Nr 92, poz. 866.

$22 \S 1$ rozporządzenia Ministra Pracy i Opieki Społecznej z dnia 26 stycznia 1925 r. w sprawie regulaminu dla Państwowych Urzędów Pośrednictwa Pracy, M. P. Nr 25, poz. 95.

${ }^{23}$ Instrukcja Ministra Pracy i Opieki Społecznej z dnia 18 stycznia 1927 r. w sprawie czynności państwowych urzędów pośrednictwa pracy w zakresie rejestracji i ewidencji wolnych miejsc 
z grudnia 1929 r., w której wskazywano, że biurokracja faktycznie zabija państwowe urzędy pracy, przez co są one mało efektywne w swej działalności, w przeciwieństwie do tych o charakterze zarobkowym ${ }^{24}$.

Każda osoba poszukująca pracy, która zgłosiła się do urzędu w godzinach jego pracy, musiała zostać zarejestrowana w obrębie zawodu, którym była zainteresowana. Jakkolwiek urząd nie był związany ,życzeniem” petenta, to zgodnie z § 4 rozporządzenia z 1925 r. urząd, delegując kandydata do pracy, miał jednak obowiązek kierowania się w pierwszej kolejności kwalifikacjami osoby bezrobotnej, jej zdolnością fizyczną do wykonania określonej pracy, jak i kolejnością wpływających wniosków ${ }^{25}$.

Pracownicy urzędu zobowiązani byli dokładnie poinformować osobę bezrobotną o warunkach pracy zadeklarowanych przez pracodawcę i częstokroć uprzednio uzgodnionych przez urząd z pracodawcą. Jeżeli bezrobotny spełniał wymagania pracodawcy, otrzymywał kartę polecającą, z którą udawał się do ewentualnego przyszłego zakładu pracy.

Pracodawca nie był związany listem polecającym z urzędu, chyba że wcześniej doszło do uzgodnienia warunków zatrudnienia. W braku porozumienia to pracodawca ostatecznie podejmował decyzję o zatrudnieniu danej osoby. Jeżeli z jakichś przyczyn nie doszło do nawiązania stosunku pracy, pracodawca mógł żądać przysłania przez urząd innych kandydatów. Sam przyszły pracownik nie miał obowiązku przyjęcia zaproponowanej mu przez urząd pracy, jednak musiał swoją decyzję uzasadnić (§ 7 rozporządzenia z 1925 r.).

Urząd pośrednictwa pracy był stroną umowy o pracę zawieranej za jego pośrednictwem. Sama umowa w swej treści była stosunkowo lakoniczna. W pierwszej kolejności określano strony umowy, następnie wysokość wynagrodzenia ${ }^{26}$ i rodzaj pracy. Dalej zamieszczano postanowienia dotyczące zwrotu kosztów podróży do pracy, które z reguły pokrywane były w $50 \%$ przez urząd pośrednictwa pracy i w $50 \%$ przez pracodawcę. Istotnymi postanowieniami umowy były zasady opieki

i poszukujących pracy, M. P. Nr 19, poz. 45. Przedmiotowa instrukcja została poprawiona dnia 25 czerwca 1928 r., M. P. Nr 144.

${ }^{24}$ Petycja właścicieli zarobkowych biur pośrednictwa pracy skierowana do Senatu RP, [w:] https://polona.pl/item/petycja-inc-dnia-10-grudnia-1929-r-zapada-termin-likwidacji-koncesjonowanych biur,NzQwMjc0MzM/0/ [dostęp: 17.11.2019].

${ }^{25}$ Dnia 21 grudnia 1918 r. Ministerstwo Pracy i Opieki Społecznej wydało obwieszczenie, określające procedurę rejestracji osób bezrobotnych, zgodnie z którym osoba bezrobotna co najmniej od dwóch tygodni zobowiązana była do uzyskania zaświadczenia od związków zawodowych lub zarządcy domu, że jest bez pracy i ukończyła 18 rok życia. Zob. E. SŁABIŃsKa, Łagodzenie skutków bezrobocia $w$ województwie kieleckim w latach 1918-1939, Kielce: Wydawnictwo Uniwersytetu Humanistyczno-Przyrodniczego Jana Kochanowskiego 2008, s. 14-15.

${ }^{26}$ Dopuszczalne było wypłacenie wynagrodzenia w formie żywności lub opału. 
zdrowotnej w przypadku choroby pracownika. Umowę tę wciągano do rejestru danego urzędu ${ }^{27}$.

Przy każdym urzędzie działały komisje o charakterze społecznym, które opiniowały ich działalność. Z mocy prawa połowa ich członków była przedstawicielami pracowników. Co ciekawe, brak było dyspozycji ustawowej co do określenia drugiej połowy składu. To, wydawać by się mogło, pozostawiono już samym stronom zainteresowanym. Przedmiotowe komisje miały być tym miejscem, gdzie pracownicy i pracodawcy spotykali się, aby dyskutować i analizować sytuację na miejscowym rynku pracy oraz stosunki gospodarcze mogące wpłynąć na rynek zatrudnienia. Komisje miały zatem faktycznie dbać o to, aby działalność biura odpowiadała lokalnym potrzebom, a także aktywnie reagować na zmiany zachodzące na rynku pracy; ewentualnie - dać samym zainteresowanym możliwość aktywnego podejmowania działań zmierzających do podniesienia zatrudnienia i jego jakości.

Niezależnie od komisji funkcjonujących przy urzędach pośrednictwa pracy celem popierania rozwoju rynku pracy, istniała możliwość powołania przy ciałach samorządowych komitetów składających się z trzech członków i tyluż samo zastępców, wybieranych przez rady samorządowe, do których zadań należało:

- ułatwienia osobom poszukującym pracy kontaktu z urzędem;

- kolportowanie biuletynów informacyjnych oraz innych obwieszczeń wydawanych przez Ministerstwo Pracy i Opieki Społecznej;

- informowanie państwowych urzędów pośrednictwa pracy o możliwościach podejmowania pracy zarobkowej w danej gminie;

- zawiadamianie władz o wszelkiego rodzaju nadużyciach popełnianych na emigrantach;

- popieranie państwowej akcji reemigracyjnej.

Niezależnie od komisji funkcjonujących na gruncie dekretu z 1919 r. w przytoczonej już publikacji Ministerstwa Pracy i Opieki Społecznej z 1921 r. wskazuje się na potrzebę powołania dodatkowych komisji społecznych o charakterze nadzorczym $^{28}$, które miałyby:

- wykonywać nadzór nad prawidłowym funkcjonowaniem i bezstronnością urzędu;

- stale pośredniczyć pomiędzy urzędem a organizacjami zawodowymi;

- inicjować działania oraz ułatwiać kontakty pomiędzy urzędem państwowym a społecznym;

- przesyłać opinie we wszystkich sprawach zleconych, a należących do kompetencji urzędu;

\footnotetext{
${ }^{27}$ APL, ZLUW, sygn. 35/403/0/7.1.4/259.

${ }^{28}$ Postulat ten nie został nigdy wdrożony w życie.
} 
- rozpatrywać zażalenia pracowników i pracodawców dotyczące działalności biura;

- występować aktywnie z wnioskami w sprawie środków zwalczania bezrobocia, szczególnie w sprawie robót publicznych.

Jednym z podstawowych obowiązków pracodawcy było informowanie urzędów pośrednictwa pracy o wolnych miejscach pracy. Obowiązek ten wynikał z treści ustawy o zabezpieczeniu na wypadek bezrobocia z 18 lipca 1924 r. ${ }^{29}$ Pracodawcy, w terminie do 3 dni, zawiadamiali właściwy urząd pracy o każdym wolnym miejscu pracy lub o zatrudnieniu nowego pracownika. Artykuł 30 tej ustawy stanowił delegację ustawową dla wydanego 31 grudnia 1924 r. rozporządzenia w sprawie obowiązku pracodawców zawiadamiania państwowych urzędów pośrednictwa pracy o każdym wolnym lub nowo obsadzonym miejscu ${ }^{30}$.

Przedmiotowe rozporządzenie było o tyle istotne, że doprecyzowywało trzydniowy termin dla wykonania obowiązku informacyjnego. Mianowicie, w zakresie wolnych miejsc pracy termin ten liczył się od dnia powzięcia informacji o wakacie lub przedsięwzięcia starań przez dany zakład pracy co do przygotowania nowego stanowiska pracy bądź obsadzenia wakatującego.

Zawiadomienie powyższe mogło być dokonane ustnie, telefonicznie lub pisemnie. Każdorazowo informacja wciągana była do ksiąg urzędu. W przypadku zgłoszeń telefonicznych wpisywano imię i nazwisko zgłaszającego, datę, godzinę i numer telefonu, z którego telefonowano. Pracodawca zobowiązany był do podania nazwy i adresu zakładu pracy, liczby deklarowanych pracowników do zatrudnienia na danym stanowisku, wymaganych kwalifikacji, warunków pracy, wysokości wynagrodzenia oraz czasu zatrudnienia ( 4 i 5). Obowiązek informacyjny dotyczył również przedsiębiorców z terenów województwa pomorskiego i poznańskiego, tutaj jednak pracodawca wprowadził reżim zawiadomień wyłącznie w formie pisemnej ${ }^{31}$.

Dekret z 1919 r., jakkolwiek społecznie ważny i oczekiwany, nie był oczywiście wolny od wad. Już w 1921 r. głośne były postulaty zastąpienia regulacji dekretowych nową kompleksową ustawą, która miała usunąć najistotniejsze mankamenty. Wskazywano potrzebę doprecyzowania przepisów, szczególnie w sferze regulującej kontakty państwowych urzędów pracy z organizacjami społecznymi, oraz regulacji dotyczących nadzoru ze strony Ministerstwa ${ }^{32}$.

\footnotetext{
${ }^{29}$ Dz. U. z 1932 r. Nr 58, poz. 555.

${ }^{30}$ Dz. U. z 1925 r. Nr 2, poz. 23.

31 § 2 rozporządzenia Ministra Pracy i Opieki Społecznej z dnia 15 lutego 1923 r. w przedmiocie zgłaszania w państwowych urzędach pośrednictwa pracy województwa poznańskiego i pomorskiego zapotrzebowań na pracowników wszelkich kategorji, Dz. U. Nr 18, poz. 123.

${ }^{32}$ Pośrednictwo pracy, s. 15.
} 
Jakkolwiek podnoszone zarzuty należy uznać za słuszne, to ustawodawca ze zmianami w systemie państwowego pośrednictwa pracy czekał aż 14 lat. W 1933 r. zniesiono państwowe urzędy pośrednictwa pracy ${ }^{33}$, których zadania zostały przekazane Funduszowi Bezrobocia ${ }^{34}$, powołanemu do życia na podstawie ustawy z dnia 18 lipca 1924 r. o zabezpieczeniu na wypadek bezrobocia, celem lepszego skoordynowania i zcentralizowania zadań w sferze pomocy bezrobotnym ${ }^{35}$. Fundusz podlegał bezpośrednio Ministrowi Pracy i Opieki Społecznej, a do jego zadań należało w pierwszym okresie przeprowadzenie akcji zasiłkowych i doraźna pomoc bezrobotnym, przede wszystkim poprzez organizowanie robót publicznych ${ }^{36}$.

Funduszowi Bezrobocia powierzono zadania z zakresu pośrednictwa pracy, które realizował za pośrednictwem biur pośrednictwa pracy i instytucji zastępczych, czyli organizacji samorządowych oraz instytucji prawno-publicznych. Zaznaczyć należy, że nowe biura wykonywały zadania analogiczne do tych powołanych na mocy dekretu z 1919 r. Doszło zatem faktycznie do ich zniesienia, a raczej do włączenia tych instytucji czy też przekazania ich zadań Funduszowi Bezrobocia, co było wyrazem nowego podejścia władz tak do funkcjonowania pośrednictwa pracy, jak i do pomocy materialnej dla osób bezrobotnych, czyli stworzenia jednolitych instrumentów pomocy bezrobotnym ${ }^{37}$.

${ }^{33}$ Proces znoszenia biur pośrednictwa pracy został rozłożony w czasie. 15 marca 1934 r. wydano rozporządzenie, w którym szczegółowo określono daty likwidacji państwowych urzędów pośrednictwa pracy w poszczególnych miastach. Przykładowo: w Lublinie urząd zniesiono 23 marca, natomiast w Warszawie 17 marca; zob. rozporządzenie Ministra Opieki Społecznej z dnia 15 marca 1934 r. o ustaleniu terminów zniesienia państwowych urzędów pośrednictwa pracy i opieki nad wychodźcami, Dz. U. Nr 22, poz. 169. Fundusz Bezrobocia przejmował zadania państwowych biur pośrednictwa pracy z chwilą ich zniesienia.

${ }^{34}$ Art. 2 rozporządzenia Prezydenta Rzeczypospolitej z dnia 27 października 1933 r. o zniesieniu państwowych urzędów pośrednictwa pracy i opieki na wychodźcami, Dz. U. Nr 84, poz. 621.

${ }^{35}$ Fundusz Bezrobocia powołano pod wypływem załamania gospodarczego z 1924 r., który spowodował znaczny wzrost bezrobocia. Fundusz miał łagodzić negatywne skutki utraty pracy. MLONEK, Bezrobocie w Polsce, s. 36.

${ }^{36}$ E. SŁABIŃSKA, Ewolucja działań publicznych służb zatrudnienia w latach 1918-1939 i 19441949. Zarys problematyki, „Optimum Economic Studies” 2 (2019), s. 98.

${ }^{37} \mathrm{~W}$ celu zorganizowania sprawnego systemu robót publicznych w 1933 r. powołano Fundusz Pracy, który zastąpił Fundusz Pomocy Bezrobotnym, por. ustawa z dnia 16 marca 1933 r. o Funduszu Pracy, Dz. U. Nr 22, poz. 163. Fundusz wykonywał zadania za pośrednictwem komitetów lokalnych oraz szeregu podległych instytucji - Biur Pośrednictwa Pracy. Dnia 24 października1934 r. scalono Fundusz Bezrobocia z Funduszem Pracy, utrzymując tę drugą nazwę, por. rozporządzenie Prezydenta Rzeczypospolitej z dnia 24 października 1934 r. o połączeniu Funduszu Bezrobocia z Funduszem Pracy, Dz. U. Nr 94, poz. 849. Rozporządzeniem Ministra Opieki Społecznej z dnia 26 marca 1935 r. o wykonywaniu przez Fundusz Pracy pośrednictwa pracy (Dz. U. Nr 23, poz. 152) w sposób szczegółowy określono zadania nowych biur w zakresie pośrednictwa pracy $(\S 2)$. Tym samym państwowe urzędy pośrednictwa pracy znalazły się pod nadzorem Funduszu Pracy. 
Ustawodawca $\mathrm{w} \S 4$ rozporządzenia o biurach pośrednictwa pracy Funduszu Bezrobocia $^{38}$ szczegółowo określił ich zadania, do których należało:

- prowadzenie rejestracji, ewidencji i kontroli osób poszukujących pracy;

- pośrednictwo pracy;

- prowadzenie clearingu pracy;

- poradnictwo zawodowe;

- wydawanie stosownych zaświadczeń;

- przyjmowanie zgłoszeń o wolnych miejscach pracy;

- czuwanie nad przestrzeganiem przepisów w zakresie zatrudniania inwalidów i inwalidów wojennych ${ }^{39}$;

- działania statystyczne;

- przyjmowanie wniosków o wypłatę zasiłków dla bezrobotnych;

- prowadzenie spraw meldunkowych robotników, w tym wydawanie zaświadczeń o ostatnim miejscu zatrudnienia;

- informowanie instytucji państwowych o odmowie przyjęcia oferty pracy przez bezrobotnego;

- kwalifikowanie pracowników do robót publicznych ${ }^{40}$;

- udzielanie informacji o krajowych stosunkach zarobkowych.

Jakkolwiek trzeba zaznaczyć, że przepisy wprowadzone w 1933 r. usunęły braki legislacyjne dekretu. Zasady rejestracji osób bezrobotnych czy delegowania ich do pracy pozostały bez zmian. Pracownicy biura nadal mieli obowiązek przyjąć każde zgłoszenie o wolnym miejscu pracy, bez względu na formę dokonania zgłoszenia, a każdy zainteresowany usługami biura musiał być przyjęty i zarejestrowany w godzinach jego urzędowania. Pracownicy biura zobowiązani byli podczas kierowania bezrobotnego do pracy kierować się jego kwalifikacjami, siłą fizyczną i wiedzą zawodową, a także stanem zdrowia i stanem rodzinnym oraz, co było nowością, zasługami na rzecz państwa (§ 9).

Utrzymano również fundamentalną zasadę funkcjonowania państwowego systemu pośrednictwa pracy: wszystkie usługi w zakresie pośrednictwa pracy były dla osób jej poszukujących bezpłatne. Jedynie pracodawcy zobowiązani byli do ponoszenia kosztów tytułem świadczonych im przez biura usług. Nowe regulacje jednak, w przeciwieństwie do uprzednich, precyzyjnie wskazywały stawki

\footnotetext{
${ }^{38}$ Rozporządzenie Ministra Opieki Społecznej z dnia 15 marca 1934 r. o biurach pośrednictwa pracy Funduszu Bezrobocia, Dz. U. Nr 22, poz. 168.

${ }^{39} \mathrm{~W}$ zakresie egzekwowania obowiązku zatrudnienia inwalidów Fundusz ściśle współpracował z inspekcją pracy. Zob. KozŁowsKi, Inspekcja pracy, s. 139.

${ }^{40}$ Kwalifikowanie i delegowanie pracowników do robót publicznych stanowiło najsłabszy punkt w procesie funkcjonowania biur pośrednictwa pracy, gdyż, co wskazuję dalej, działalność biur ograniczała się wyłącznie do organizowania tych prac, por. SŁABIŃSKA, Ewolucja działań, s. 100-101.
} 
pobierane od pracodawców. I tak za pozyskanie artysty widowiskowego należne wynagrodzenie dla biura wynosiło 5\% jego wynagrodzenia, w przypadku służby domowej było to 2 zł od osoby. Wysokość wynagrodzenia za pozyskanie pracowników pozostałych profesji uzależniona była od liczby pracowników jednorazowo zatrudnianych: pracodawca płacił 50 gr od każdego pracownika, jeśli zatrudniał 1-5 pracowników. Przy zatrudnieniu 5-20 pracowników było to już 35 gr, a powyżej 20 pracowników wynagrodzenie wynosiło 20 gr (§ 23).

\section{SPOŁECZNE BIURA POŚREDNICTWA PRACY}

Społeczne pośrednictwo pracy uzupełniało system państwowego pośrednictwa pracy. Przystępując do prac nad ustawą, która miała ujednolicić ich działalność, rozpoczęto od przeprowadzenia badań ankietowych, które rozesłano do funkcjonujących już społecznych biur, aby w ten sposób pozyskać niezbędne informacje, tak o samych organizacjach, które takie biura prowadziły, ale przede wszystkim, aby dowiedzieć się, jaki był ich wpływ na pośrednictwo pracy w Polsce. W efekcie uznano, że biura te powinny nadal funkcjonować i aktywnie uzupełniać system państwowego pośrednictwa pracy. Jednocześnie uchwalono ustawę z 10 czerwca 1924 r. o społecznym pośrednictwie pracy ${ }^{41}$, która w sposób kompleksowy dla całego kraju regulowała zasady ich powoływania i funkcjonowania.

Prawo do wykonywania usług społecznego pośrednictwa pracy miały jedynie organizacje i instytucje społeczne o charakterze niezarobkowym, które uzyskały stosowne zezwolenie ${ }^{42}$, a ich celem statutowym było społeczne pośrednictwo pracy (art. 1). Jednocześnie przyjęto zasadę, że tego typu działalność mogła być prowadzona jedynie poprzez wyspecjalizowane biuro $w$ ramach struktur organizacyjnych danej organizacji, które zajmowało się wyłącznie pośrednictwem zawodowym dla swoich członków.

Prawo do prowadzenia społecznych biur pośrednictwa pracy posiadały jedynie te organizacje społeczne, które wciągnięte były do właściwych (według ich siedziby) rejestrów stowarzyszeń. W byłym zaborze rosyjskim dla stowarzyszeń z Warszawy rejestr prowadził Minister Spraw Wewnętrznych. Pozostałe organi-

\footnotetext{
${ }^{41}$ Dz. U. Nr 58, poz. 585.

${ }^{42}$ Pozwolenia udzielał Minister Pracy i Opieki Społecznej, zgodnie jednak z postanowieniami $\S 3$ rozporządzenia wykonawczego Ministra Pracy i Opieki Społecznej z dnia 25 lipca 1924 r. do ustawy z dnia 10 czerwca 1924 r. o społecznym pośrednictwie pracy, minister delegował to uprawnienie na wojewodów (Dz. U. Nr 67, poz. 652 z późn. zm.), co zostało potwierdzone na mocy art. 116 rozporządzenia Prezydenta Rzeczypospolitej z dnia 28 grudnia 1934 r. o unormowaniu właściwości władz i trybu postępowania w niektórych działach administracji państwowej, Dz. U. Nr 110, poz. 976.
} 
zacje rejestrowano w urzędzie wojewódzkim lub Delegaturze Rządu w Wilnie. Właściwe urzędy wojewódzkie prowadziły również rejestry na terenie byłego zaboru austriackiego i w cieszyńskiej części województwa śląskiego. W zaborze pruskim, stowarzyszenie musiało uzyskać wpis do rejestru prowadzonego przez sądy powiatowe ${ }^{43}$.

Wspomniałem już, że społeczne biura pośrednictwa pracy miały ściśle współpracować z państwowymi urzędami. Co jednak ciekawe, zobowiązane one zostały również do przekazania całej swojej wiedzy państwowym urzędom na temat technicznej strony ich działalności jako organizacje posiadające większe doświadczenie w zakresie pośrednictwa pracy ${ }^{44}$.

Niezależnie od obowiązku uprzedniego uzyskania pozwolenia i wyodrębnienia w swoich strukturach organizacyjnych wyspecjalizowanego biura organizacje te musiały dodatkowo spełnić następujące warunki:

- wyznaczyć kierownika biura;

- zawiadomić właściwy państwowy urząd pracy o utworzeniu biura;

- uchwalić regulamin działania biura.

Społeczne biura pośrednictwa pracy funkcjonowały na podstawie pozwolenia wydawanego przez wojewodę. By zobrazować poszczególne etapy jego wydawania, przedstawię ten proces na przykładzie zezwolenia udzielonego Zjednoczeniu Zawodowemu „Praca Polska”, które prowadziło biuro pośrednictwa pracy w Lublinie.

Pierwszym krokiem było oczywiście wniesienie podania do wojewody, które było wnioskiem o wydanie stosownego pozwolenia. Samo podanie wymagało zachowania formy pisemnej, przy czym brak było formularza urzędowego. W analizowanej sprawie zarząd Okręgu Lubelskiego Zjednoczenia podaniem z 8 marca 1938 r., zwrócił się do wojewody lubelskiego o wydanie pozwolenia (prawa) na prowadzenie społecznego biura pośrednictwa pracy, wskazując jako cel pośrednictwo pracy dla członków stowarzyszenia „Praca Polska”. Jednocześnie wskazywano $\mathrm{w}$ podaniu, że $\mathrm{z}$ chwilą uzyskania pozwolenia wyodrębnione zostanie stosowne biuro oraz powołany zostanie kierownik, jako osoba odpowiedzialna za prowadzenie biura i dokumentację. Do podania załączano statut i wskazywano jego postanowienia, że jednym z celów organizacji było właśnie prowadzenie społecznego biura pośrednictwa pracy. Podanie podlegało

${ }^{43} \S 1$ rozporządzenia wykonawczego do ustawy z dnia 10 czerwca 1924 r. o społecznym pośrednictwie pracy.

${ }^{44}$ Pośrednictwo pracy, s. 94 n. 
opłacie stemplowej w kwocie 5 zł, którą uiszczono, poprzez naklejenie znaków skarbowych na podaniu ${ }^{45}$.

Po wpłynięciu podania do urzędu wojewódzkiego kierowano zapytanie, wówczas już do Biura Funduszu Pracy, czy istnieją przeszkody w udzieleniu stosownego pozwolenia. W odpowiedzi z 29 kwietnia 1938 r. Fundusz pozytywnie odniósł się do idei powstania lubelskiego biura pośrednictwa pracy, jednak zobowiązał je do przedstawiania miesięcznych sprawozdań ze swojej działalności i ścisłego przestrzegania przepisów z zakresu pośrednictwa pracy.

Wobec braku przeszkód wojewoda lubelski wydał 12 maja 1938 r. zaświadczenie, w którym stwierdzono, że Zjednoczenie Zawodowe „Praca Polska” uprawnione było do wykonywania społecznego pośrednictwa pracy na rzecz swoich członków. Przedmiotowe zaświadczenie ważne było do 31 grudnia 1938 r. Jednocześnie zastrzeżono, że w razie stwierdzenia nikłej działalności udzielone pozwolenie może być cofnięte wcześniej.

Ostatnim etapem było już tylko skierowanie informacji przez kierownika społecznego biura pracy do wojewody, zawiadamiające go o rozpoczęciu działalności. $\mathrm{W}$ analizowanej sprawie, pismem kierownik poinformował wojewodę, że z dniem 1 czerwca 1938 r., przystąpiono do swoich czynności. Wskazano również: 1) adres biura, w tym wypadku: Lublin, ul. Krakowskie Przedmieście 36, lewa oficyna, 1 piętro, tel. 22-77; 2) godziny urzędowania, tj. 10-12 i 18-19; 3) personel biura z podaniem ich adresów domowych ${ }^{46}$.

Ciekawym rozwiązaniem, dla którego jednak osobiście nie znajduję uzasadnienia, było znaczące ograniczenie możliwości wykonywania działalności gospodarczej przez kierowników i pracowników społecznych biur pośrednictwa pracy, którzy nie mogli prowadzić działalności gospodarczej, np. w przedmiocie sprzedaży napojów alkoholowych, prowadzenia hoteli, wynajmu pokoi, handlu odzieżą czy wymiany pieniędzy ${ }^{47}$.

Społeczne urzędy pracy, zgodnie z art. 4, podobnie jak państwowe, swoją działalność mogły wykonywać wyłącznie niezarobkowo. Uprawnione były jedynie do pobierania od pracodawców opłaty w wysokości 5\% pierwszego miesięcznego zarobku pracownika. Zakazane było pobieranie innych opłat.

Ustawodawca nałożył na społeczne biura pracy szereg wymogów, których należało przestrzegać, aby zagwarantować ich profesjonalizm i zapewnić swoistą

${ }^{45}$ Ustawa z dnia 1 lipca 1926 r. o opłacie stemplowej, wprowadziła obowiązek zapłaty opłaty stemplowej od wszelkich pism stwierdzających czynność prawną oraz od czynności prawnych niesporządzonych w formie pisemnej, Dz. U. z 1935 r. Nr 64, poz. 404 z późn. zm.

${ }^{46}$ APL ZLUW, syg. 35/403/0/7.1.4/214

${ }^{47}$ Zakaz ten dotyczył również pracowników oraz osób, które pozostawały z nimi we wspólnym gospodarstwie domowym. 
transparentność ich działania. Po pierwsze, każde zgłoszenie, które wpłynęło do biura musiało być zarejestrowane i posegregowane według zawodów. Po drugie, prowadzone rejestry były każdorazowo aktualizowane. Po trzecie, kierując do pracy osobę bezrobotną należało zachować zasadę kolejności zgłoszeń oraz zaopatrzyć kandydata w kartę polecającą. Po czwarte, wysokość wynagrodzenia biura musiała być uwidoczniona w księgach rachunkowych. W końcu, społeczne biuro pracy obowiązane było przesyłać raz w miesiącu, do właściwego państwowego urzędu pośrednictwa pracy, sprawozdanie ze swojej działalności.

Oczywiście brak przestrzegania powyższych obowiązków narażał społeczne biuro pracy na sankcje. Były to kary grzywny wynoszące od 10 do $250 \mathrm{zl}$, wymierzane przez sądy powiatowe, które dodatkowo mogły orzec o zakazie prowadzenia działalności społecznego pośrednictwa pracy przez kolejne 3 lata.

W przypadku czerpania korzyści majątkowych podczas wykonywania swoich zadań, biuro takie traktowano jak przedsiębiorstwo trudniące się zarobkowym pośrednictwem pracy i podlegało pod reżim przepisów dotyczących zarobkowych biur pracy.

W większości sytuacji biura społeczne były powoływane przez zawodowe organizacje samorządowe w celu uporządkowania systemu obsadzania stanowisk w ramach danej grupy zawodowej czy usunięcia niezdrowego współzawodnictwa w danym zawodzie. Przykładowo, w 1935 r. na podstawie art. 4 pkt 5 ustawy z dnia 15 marca 1934 r. o Izbach Lekarskich ${ }^{48}$ uchwalono Regulaminu Biur Pośrednictwa Pracy przy Izbie Lekarskiej Lubelskiej ${ }^{49}$. Zgodnie z art. 1 regulaminu powołano społeczne biuro w celu pośrednictwa i współudziału Izby Lekarskiej przy obsadzaniu płatnych stanowisk pracy lekarskiej. Co więcej, wprowadzono zasadę, że wszystkie płatne stanowiska pracy miały być obejmowane przez lekarzy jedynie za pośrednictwem i przy współudziale utworzonego biura pod rygorem pociągnięcia lekarza do odpowiedzialności przed Izbą (art. 2$)^{50}$.

Zadaniem pracowników biura było również zbieranie zawiadomień o konkursach na wolne stanowiska pracy, nawiązywanie i utrzymywanie stałych kontaktów we wszelkich sprawach dotyczących zatrudniania lekarzy, zbieranie informacji o wolnych miejscach pracy, sprawdzanie warunków pracy i płacy lekarskiej oraz informowanie o tym zarządu Izby.

Podstawą nawiązywania stosunku pracy w świetle powyższego regulaminu był konkurs. W pierwszej kolejności pracodawca zawiadamiał biuro o zamiarze

\footnotetext{
${ }^{48}$ Dz. U. Nr 31, poz. 275.

${ }^{49}$ Dz. Urz. Izb Lekarskich z 1935 r. Nr 4, [w:] https://polona.pl/item/regulamin-biura-posrednictwa-pracy-przy-izbie-lekarskiej-lubelskiej,NzE2NDM0MTY/0/\#info:metadata [dostęp: 7.11.2019].

${ }^{50}$ Obowiązek ten nie dotyczył stanowisk związanych z wojskową służbą zdrowia, stanowisk w państwowych urzędach czy stanowisk naukowych w zakładach akademickich.
} 
ogłoszenia konkursu na wolną posadę, w treści którego podawał warunki konkursu, żądane dokumenty oraz termin nadsyłania zgłoszeń. Następnie biuro, niezależnie od ogłoszenia pracodawcy, publikowało ogłoszenie o konkursie w swoim organie prasowym, względnie w innych poczytnych czasopismach (art. 5). Po upływie wskazanego w ogłoszeniu terminu zbierała się komisja kwalifikacyjna biura pośrednictwa pracy i po rozpatrzeniu ofert oraz przejrzeniu dokumentów aplikacyjnych ustalała kwalifikacje etyczne, zawodowe i materialne poszczególnych kandydatów - biuro zestawiało kandydatów w kolejności osiągniętych wyników i wysyłało ich podania pracodawcy. W przypadku, gdy ilość ofert na dane wolne stanowisko wynosiła trzy lub więcej, wówczas pracodawcy przesyłano listę w kolejności z trzema nazwiskami kandydatów. Ostatecznie to pracodawca dokonywał wyboru pracownika spośród przedstawionych mu kandydatów (art. 9 i 10$)^{51}$.

Lekarz, który otrzymał tą drogą pracę, zobowiązany był do zapłacenia Izbie kwoty 5\% miesięcznego wynagrodzenia jako zwrot kosztów manipulacyjnych.

\section{ZAROBKOWE POŚREDNICTWO PRACY}

Wiemy już, że przedsiębiorcy uprawnieni byli do prowadzenia działalności gospodarczej w zakresie zarobkowego świadczenia usług pośrednictwa pracy. Wobec kontrowersji, jakie budził ten temat, i faktu, że przedsiębiorstwa te funkcjonowały na podstawie regulacji zaborczych, a ustawodawca ostatecznie nie zabronił tego typu działalności, pilną potrzebą było jej ustawowe uregulowanie, w tym poddanie ścisłej kontroli państwa.

Nie czekając na przyjęcie kompleksowej ustawy regulującej sferę podejmowania i wykonywania działalności gospodarczej 21 października 1921 r. uchwalona została ustawa o zarobkowym pośrednictwie pracy ${ }^{52}$. Ustawa ta, oprócz oczywiście kompleksowego uregulowania zasad podejmowania działalności gospodarczej w sferze zawodowego pośrednictwa pracy, poddała ją ścisłej kontroli państwa.

Analogicznie do sytuacji społecznych biur pośrednictwa pracy uchwalenie powyższej ustawy poprzedzone zostało swoistą lustracją już istniejących zawodowych przedsiębiorstw zajmujących się odpłatnym pośrednictwem pracy. Zebrano w ten sposób informacje tak co do formy i podstawy prawnej, jak i efektów ich działalności. Ciekawa jest jednak sama konkluzja tej lustracji: Ministerstwo Pracy

${ }^{51}$ Zob. też Regulamin Biura Pośrednictwa Pracy Wileńsko-Nowogrodzkiej Izby Lekarskiej z dnia 25 czerwca 1929 r., Dz. Urz. z 1929 r. Nr 225, [w:] https://polona.pl/item/regulamin-biura-posrednictwa-pracy-wilensko-nowogrodzkiej-izby-lekarskiej,NzE2NDM0NDk/2/\#info:metadata [dostęp: 9.11.2019].

${ }^{52}$ Dz. U. Nr 88, poz. 647. 
i Opieki Społecznej, stwierdziło, że działalność ta była ekonomicznie nieuzasadniona. Ruch w biurach był bardzo mały, a dokumentację prowadzono w sposób niechlujny, co uniemożliwiało ich rzetelną kontrolę ${ }^{53}$. Co więcej, analizując stanowisko polustracyjne, dochodzimy do wniosku, że dopuszczenie przedsiębiorstw zarobkowego pośrednictwa było jedynie rozwiązaniem tymczasowym, do chwili opanowania rynku pośrednictwa pracy przez państwowe urzędy. Do tego jednak czasu przedsiębiorstwa zawodowe miały uzupełnić system państwowego pośrednictwa pracy. Chyba tylko dlatego nie doszło do ich likwidacji, a wręcz przeciwnie - na gruncie ustawy pozwolono na otwieranie kolejnych.

W pierwszej jednak kolejności należało uporządkować sposób działania już istniejących. Osoby z terenów byłego zaboru rosyjskiego, które 10 grudnia $1921 \mathrm{r}$. posiadały ważne pozwolenie na wykonywanie zarobkowego pośrednictwa pracy, zobowiązane zostały, do 10 marca 1922 r., do wniesienia do właściwego urzędu wojewódzkiego podania o udzielenie pozwolenia na działalność podług nowego prawa. Przedsiębiorcy z pozostałych terenów Rzeczypospolitej zostali zobowiązani, również w tym samym terminie, do odnowienia pozwoleń i aktualizacji dokumentacji ${ }^{54}$.

Stosownie do założeń ustawodawcy zarobkowe pośrednictwo pracy objęte zostało obowiązkiem koncesyjnym ${ }^{55}$. Pozwolenie wydawane było przez Ministra Pracy i Opieki Społecznej na rok, po uprzednim zapłaceniu kaucji ${ }^{56}$. Ulegało ono odnowieniu, o ile wniesiono na trzy miesiące przed upływem ważności pozwolenia podanie o przedłużenie ${ }^{57}$. Co ważne, wniesienie podania uprawniało do dalszego wykonywania zarobkowego pośrednictwa pracy, aż do rozstrzygnięcia sprawy.

${ }^{53}$ Pośrednictwo pracy, s. 64-65.

54 §1 i 2 rozporządzenia Ministra Pracy i Opieki Społecznej i Ministra b. dzielnicy Pruskiej w przedmiocie wykonania ustawy z dnia 21 października $1921 \mathrm{r}$. o zarobkowym pośrednictwie pracy z dnia 30 stycznia 1922 r., Dz. U. Nr 10, poz. 82.

${ }^{55}$ Stosownie do postanowień rozporządzenia Ministra Pracy i Opieki Społecznej i Ministra b. Dzielnicy Pruskiej z dnia 30 stycznia 1922 r. w przedmiocie wykonania ustawy z dnia 21 października 1921 r. o zarobkowym pośrednictwie pracy, podanie o udzielenie pozwolenia wnosiło się za pośrednictwem wojewody. Ostatecznie jednak na podstawie art. 117 rozporządzenia Prezydenta Rzeczypospolitej z dnia 28 grudnia 1934 r. o unormowaniu właściwości władz i trybu postępowania w niektórych działach administracji państwowej kompetencje te zostały przekazane wojewodzie.

${ }^{56}$ Wysokość kaucji ustalono na kwotę 150 zł dla jednej grupy pracowników i 300 dla dwóch lub więcej grup. Rozporządzenie Ministra Pracy i Opieki Społecznej z dnia 28 maja 1924 r. w przedmiocie ustalenia kaucji zarobkowych pośredników pracy, Dz. U. Nr 50, poz. 511. Wysokość kaucji ulegała zmianie. Pierwotnie wynosiła $100000 \mathrm{mk}$ dla jednej grupy pracowników i $300000 \mathrm{mk}$ dla wszystkich kategorii (§ 6 rozporządzenia wykonawczego), później odpowiednio: $10000000 \mathrm{mk}$ i 20000000 mk, rozporządzenie Ministra Pracy i Opieki Społecznej z dnia 28 listopada 1923 r. w przedmiocie zmian w rozporządzeniu z dnia 30 stycznia 1922 r. do ustawy o zarobkowem pośrednictwie pracy, Dz. U. Nr 126, poz. 1031.

${ }^{57}$ Podanie wnoszono za pośrednictwem właściwego urzędu wojewódzkiego. 
Zatem można przyjąć, że gdyby urząd nie rozstrzygnął sprawy w przeciągu trzech miesięcy, pozwolenie było ważne dłużej niż 12 miesięcy (art. 6).

Trzeba przyznać, że ustawodawca nie wprowadził zbyt wygórowanych wymogów dla podmiotów chcących podjąć działalność zarobkowego pośrednictwa pracy. Ministerstwo odmawiało wydania pozwolenia w sytuacji, gdy zarówno podmiot wnoszący podanie, jak i osoby pozostające $\mathrm{z}$ nim $\mathrm{w}$ jednym gospodarstwie domowym nie dawały swoim postępowaniem gwarancji, że działalność przez nie prowadzona będzie wykonywana zgodnie z prawem i dobrymi obyczajami oraz gdy w danej miejscowości istniała już dostateczna liczba pośredników zarobkowych.

Pozwolenie dotyczyło jedynie osoby pośrednika. Prowadzenie działalności przez pełnomocnika wymagało zgody Ministra Pracy i Opieki Społecznej. Zakazane było również wykonywanie tej działalności w formie spółki prawa handlowego.

Istniał także szereg ograniczeń co do określenia wzajemnych praw i obowiązków pośrednika pracy i osoby poszukującej pracy. W pierwszej kolejności nieważne były wszelkie umowy opatrzone klauzulą wyłączności lub zobowiązujące do korzystania z uzyskanego miejsca pracy dłużej niż przez określony czas. Dodatkowo pośrednik zobowiązany był powiadomić poszukującego pracy o wysokości wynagrodzenia za jego usługi. Nieważne były postanowienia umowy, które zawierały wszelkiego rodzaju opłaty czy kaucje dodatkowe poza wynagrodzeniem określonym w umowie.

Wspomnieć należy, że 7 czerwca 1927 r. prezydent wydał rozporządzenie o prawie przemysłowym ${ }^{58}$ - dekret fundamentalny z punktu widzenia podejmowania i wykonywania działalności gospodarczej, który materię tę regulował w sposób kompleksowy dla całego kraju. W zakresie przedmiotowym ustawa odnosiła się do zasad podejmowania i prowadzenia działalności gospodarczej, w zakresie podmiotowym określiła pojęcie przedsiębiorcy, czyli osoby prowadzącej we własnym imieniu działalność gospodarczą ${ }^{59}$. Niestety, podstawową wadą prawa przemysłowego był szeroki katalog działalności wyłączonych spod jego obowiązywania. Dotyczyło to m.in. zarobkowego pośrednictwa pracy. Tym samym pomimo wejścia $\mathrm{w}$ życie „konstytucji działalności gospodarczej” nadal jedynym aktem normatywnym regulującym działalność gospodarczą w zakresie zarobkowego pośrednictwa pracy pozostała ustawa z dnia 21 października $1921 \mathrm{r}$.

Jakkolwiek prawo przemysłowe nie miało zastosowania do zarobkowego pośrednictwa pracy, to nie sposób analizować przepisów tej ustawy w oderwaniu

\footnotetext{
${ }^{58}$ Dz. U. Nr 53, poz. 468.

${ }^{59}$ Do czasu wejścia w życie prawa przemysłowego obowiązywały: austriacka ustawa o przemyśle fabrycznym i przemysłowym z 1859 r., niemiecka ustawa o przemyśle fabrycznym i przemysłowym z 1869 r., postanowienie Księcia Namiestnika Królewskiego z 31 grudnia 1816 r. urządzające zgromadzenie rzemieślnicze, postanowienie Księcia Namiestnika Królewskiego z 11 stycznia 1817 r. o urządzeniu kupiectwa, rosyjska ustawa o przemyśle oraz rosyjska ustawa handlowa.
} 
od prawa przemysłowego, przede wszystkim w kontekście zdefiniowania pojęcia działalności gospodarczej czy samego przedsiębiorcy. Zgodnie z art. 1 ustawy o zarobkowym pośrednictwem pracy była to działalność zawodowa prowadzona w zakresie pośredniczenia $\mathrm{w}$ zawieraniu umów o pracę oraz gromadzenia ogłoszeń na temat rynku pracy ${ }^{60}$, chociaż osoba, która podjęła się tego typu działalności, nie podlegała pod przepisy prawa przemysłowego, a zatem nie musiała dokonać zgłoszenia rozpoczęcia prowadzenia działalności gospodarczej władzy przemysłowej I instancji właściwej dla miejsca jej prowadzenia (art. 7 prawa przemysłowego).

Ponownie należy wskazać, że zgodnie z ówczesnym trendem międzynarodowym, zarobkowe pośrednictwo pracy było formą działalności niepożądaną przez państwo. Było to oczywiście stanowisko ustawodawcy. Widząc potrzebę całościowego przedstawienia sprawy, należy wskazać też stanowisko samych przedsiębiorców wykonujących tego typu działalność. Tutaj, chciałbym ponownie przywołać treść petycji skierowanej do senatorów z 1929 r., a z lektury, której wyłania się zgoła odmienny obraz zawodowego oraz państwowego pośrednictwa pracy, w porównaniu do tego przedstawionego przez Ministerstwo Pracy i Opieki Społecznej. Przedmiotowa petycja, bowiem była wyrazem protestu wobec faktu, że z dniem 10 grudnia 1929 r. likwidowano koncesjonowane biura pośrednictwa pracy dla służby domowej. Wnioskodawcy w pierwszej kolejności wskazali na szkodliwe działanie Ministerstwa Pracy i Opieki Społecznej, które ogranicza działalność prywatną, kieruje kraj w stronę etatyzmu. Zwrócono uwagę, że likwidacja zawodowych biur pośrednictwa pracy, to wyraz działań na szkodę samych bezrobotnych, gdyż biura te pośredniczyły rocznie w zawarciu ponad miliona umów o pracę i uzupełniały

${ }^{60}$ Prawo przemysłowe, a tym samym prawo publiczne, nie posługiwało się pojęciem działalności gospodarczej, lecz pojęciem przemysłu w celu zdefiniowania prowadzonej działalności zarobkowej. Definicja ustawowa działalności gospodarczej (przemysłu) opracowana została na podstawie osiągnięć judykatury niemieckiego prawa przemysłowego i było to wszelkie zatrudnienie lub przedsiębiorstwo wykonywane samoistnie, zarobkowo oraz zawodowo, bez względu na to, czy było działalnością wytwarzającą, przetwarzającą, handlową bądź usługową (art. 1 prawa przemysłowego). Analizując powyższą definicję, należało wyróżnić trzy podstawowe cechy, które musiały występować łącznie, aby daną działalność uznać za przemysł: musiała mieć charakter zarobkowy, samoistny i zawodowy. Działalność musiała być prowadzona w sposób zarobkowy, czyli obliczona na zysk, obojętne było jednak, czy takowy został osiągnięty. Wystarczające było założenie, że dana działalność przyniesie zysk, bez względu na jego wysokość i sam fakt jego osiągnięcia. Samoistność należało rozumieć jako podejmowanie działań we własnym imieniu, na własny rachunek, jak i na własną odpowiedzialność, nie będąc zastępcą $\mathrm{w}$ rozumieniu art. 5 prawa przemysłowego ani pracownikiem zatrudnionym na podstawie umowy o pracę. Przesłanka zawodowości rozumiana była jako trwałość w prowadzeniu działalności. Czynności bazujące na jednorazowych zdarzeniach nie miały charakteru zawodowego. Oceniając, czy dana działalność miała charakter zawodowy, miarodajny nie był jedynie czas, gdyż istniały tzw. prace sezonowe, ze swej natury krótkotrwałe, a cechujące się przesłanką zawodowości. Zob. S. KwIEcIEŃ, Polskie prawo gospodarcze okresu międzywojennego, Lublin: Wydawnictwo KUL 2016, s. 30-31. 
system państwowy. Co więcej, według wnioskodawców ich działalność była bardziej efektywna i tańsza w przeciwieństwie do państwowych urzędów pośrednictwa pracy, które były instytucjami organizacyjne niewydolnymi ${ }^{61}$. Opis ten w żaden sposób nie koresponduje $\mathrm{z}$ informacjami przytoczonymi w poprzedniej części artykułu, a dotyczącymi zawodowych biur pośrednictwa pracy.

\section{PODSUMOWANIE}

Wysokie bezrobocie w Polsce okresu międzywojennego było niewątpliwie jednym z największych problemów społeczno-gospodarczych, z jakimi musiało się zmierzyć odrodzone państwo. Problem ten niewątpliwie wzmacniały niekorzystne czynniki tak zewnętrzne, jak i wewnętrzne. Zaliczyć tu należy proces odbudowy i jednoczenia państwa, kryzysy ekonomiczne, niewątpliwie silniej odczuwalne w państwach takich jak Polska, odciskały swe piętno na rynku pracy.

Podstawowym instrumentem do walki z bezrobociem miały być państwowe urzędy pośrednictwa. To państwo postanowiło w sposób władczy zaingerować w sferę ochrony osób bezrobotnych i w ten sposób, zgodnie ze swoimi założeniami, pozytywnie wpłynąć na politykę zatrudnienia, przeciwdziałając bezrobociu. Jednocześnie dopuszczono społeczne biura pośrednictwa pracy i prywatne przedsiębiorstwa zarobkowe, które miały uzupełnić system pośrednictwa pracy i pomocy bezrobotnym.

Ocena systemu pośrednictwa pracy w Polsce okresu międzywojennego, jak i procesu jego budowy, nie jest zadaniem łatwym. Chciałbym najpierw przedstawić pewne założenie, które przyświecało ustawodawcy, tworzącemu państwowy system pośrednictwa pracy w odrodzonym kraju, a które pozwolę sobie spuentować już na samym końcu: „[...] jednocześnie z rozwojem życia gospodarczego biura pośrednictwa pracy muszą się stać czemś więcej aniżeli tylko lokalem, gdzie miejscowy pracodawca spotyka się z miejscowym pracownikiem, przez co biuro ułatwia zawarcie umowy. Jeżeli do biura pośrednictwa pracy, zgłoszą się robotnicy, a wolnych miejsc dla nich nie ma, to do zadań pracownika należy starać się o to, aby je, o ile możności, wynaleźć”62.

Jest to o tyle ważne, że państwowe urzędy pośrednictwa pracy, chociaż same miały pomagać osobom bezrobotnym w znalezieniu zatrudnienia, borykały się z problemami typowymi dla tamtego okresu, tzn. brakiem funduszy na swą działalność. Ciężko realizować zadania ustawowe, skoro w biurze brakowało opału,

\footnotetext{
${ }^{61}$ Petycja wtaścicieli.

${ }^{62}$ Pośrednictwo pracy, s. 10.
} 
a wydziały aprowizacyjne urzędów miast, w których biura miały siedzibę, nie zapewniały go w ilościach wnioskowanych ${ }^{63}$. Niejednokrotnie urzędy borykały się też z problemami lokalowymi. Państwowy Urząd Pośrednictwa Pracy w Lublinie pismem z 13 sierpnia 1919 r. zwrócił się do Ministerstwa, aby te pokryło jego zaległości czynszowe oraz zapłaciło za szkody wyrządzone przez osoby poszukujące pracy, w kamienicy, w której mieściło się biuro ${ }^{64}$.

Czy możliwe było zatem istnienie prawidłowo funkcjonującego aparatu pośrednictwa pracy, który bazował na informacjach, które nie odzwierciedlały stanu zgodnego z rzeczywistym? Pytanie jest istotne w kontekście informacji o wysokości i przyczynach bezrobocia w Polsce, przedstawionych na wstępie, w zestawieniu z analizą raportów tygodniowych i miesięcznych państwowego urzędu pośrednictwa pracy w Lublinie z lat 1919-1939. Te z jednej strony nie potwierdzają informacji o ułomnościach systemu rejestracji osób bezrobotnych, jak i działalności państwowych urzędów pośrednictwa pracy. $Z$ drugiej strony, potwierdza się teza postawiona przez ówczesnych przedsiębiorców w swojej petycji z 1929 r., w której piszą o państwowych urzędach jako instytucjach mało mobilnych, kierujących pracowników jedynie do prac sezonowych i na roboty publiczne. Analizowane raporty o stanie bezrobocia każdorazowo zawierały dosyć szczegółowe informacje na temat skali tego zjawiska na danym obszarze, jak i jego przyczyn. Czytamy w nich, że spadki i wzrosty wskaźnika bezrobocia ściśle powiązane były z rozpoczęciem i zakończeniem prac sezonowych w rolnictwie i ilością zlecanych robót publicznych. Zawierały one również swoistą analizę przyczyn takiego, a nie innego stanu rzeczy w opisywanym okresie sprawozdawczym. Przykładowo, w raporcie z 4 grudnia 1933 r. za miesiąc listopad wskazano, że stwierdzony wzrost bezrobocia był wynikiem zakończenia kampanii cukrowej i sezonu prac publicznych. Kiedy w raporcie z 4 października 1993 r., za miesiąc wrzesień czytamy, że stopa bezrobocia spada, z uwagi na rozpoczęcie kampanii cukrowej i trwający sezon robót publicznych. Wprost jest mowa o zakontraktowaniu ponad 900 pracowników do prac sezonowych ${ }^{65}$.

Czy zatem powołany w okresie międzywojennym system państwowego pośrednictwa pracy spełniał swoje zadania i odzwierciedlał założenia Ministerstwa Pracy i Opieki Społecznej wyrażone w 1921 r.? Z czego wynikały wskazane przez przedstawicieli zarobkowych biur pośrednictwa pracy niedoskonałości funkcjonowania państwowych urzędów? Czy był to efekt braku środków na swą działalność, znacznego formalizmu działania, braku rzetelnej informacji o rynku pracy, czy

\footnotetext{
${ }^{63}$ APL ZLUW, sygn. 35/403/0/7.1.4/256.

${ }^{64}$ APL ZLUW, sygn. 35/412/0/16/488.

${ }^{65}$ APL ZLUW, syg. 35/403/0/2/324 oraz 35/403/0/2/325.
} 
może jednak były to instytucje w sposób prawidłowy wykonujące swe działania? Odpowiedzią niech będzie ponownie stanowisko właścicieli zarobkowych biur pośrednictwa pracy, którzy przedstawili negatywny obraz społecznych biur pośrednictwa pracy, a zatem systemu opartego na państwie: „,...] dziesięcioletnia praktyka wykazała, że urzędy państwowe w tym dziale są tylko surogatem pośrednictwa i stały się bezduszną oderwaną od życia biurokratyczną papierową procedurą kancelaryjną i że Państwowe Urzędy Pracy w stosunku do służby domowej muszą się stać czymś więcej jak lokalem państwowym [...]"66.

Według nich, państwowe urzędy stały się tym, czym miały się nie stać, czyli biurokratycznymi, niewydolnymi organizmami, których działania faktycznie sprowadzały się do kierowania osób na roboty publiczne i prace sezonowe. Czy był to jednak obraz osób broniących swoich źródeł dochodu? Jakkolwiek podsumowując, niewątpliwie w ciągu 5 lat stworzono zwarty system pośrednictwa pracy, oparty na państwowych urzędach, wspomaganych przez system społecznego i zarobkowego pośrednictwa pracy.

\section{BIBLIOGRAFIA}

\section{ŹRÓDEA ARCHIWALNE}

Archiwum Państwowe w Lublinie, Zespół Lubelski Urząd Wojewódzki, sygn. 35/403/0/2/324; $35 / 403 / 0 / 2 / 325 ; 35 / 403 / 0 / 7.1 .4 / 259 ; 35 / 403 / 0 / 7.1 .4 / 214 ; 35 / 403 / 0 / 7.1 .4 / 256 ; 35 / 412 / 0 / 16 / 488$.

\section{ŹRÓDŁA PRAWA}

Międzynarodowa Konwencja w sprawie pośrednictwa pracy dla marynarzy, przyjęta jako projekt dnia 10 lipca 1920 r. w Genui na Ogólnej Konferencji Międzynarodowej Organizacji Pracy Ligi Narodów, ratyfikowana zgodnie z ustawą z dnia 19 grudnia 1923 r., Dz. U. z 1925 r. Nr 54, poz. 374. Dekret Naczelnika Państwa z dnia 27 stycznia 1919 r. o organizacji państwowych urzędów pośrednictwa pracy i opieki na wychodźcami, Dz. P. P. Nr 11, poz. 127.

Ustawa z dnia 17 marca 1921 r. - Konstytucja Rzeczypospolitej Polskiej, Dz. U. Nr 44, poz. 267.

Ustawa z dnia 21 października 1921 r. o zarobkowym pośrednictwie pracy, Dz. U. Nr 88, poz. 647. Ustawa z dnia 10 czerwca 1924 r. o społecznym pośrednictwie pracy, Dz. U. Nr 58, poz. 585.

Ustawa z dnia 18 lipca 1924 r. o zabezpieczeniu na wypadek bezrobocia, Dz. U. z 1932 r. Nr 58, poz. 555.

Ustawa z dnia 1 lipca 1926 r. o opłacie stemplowej, Dz. U. z 1935 r. Nr 64, poz. 404 z późn. zm. Ustawa z dnia 16 marca 1933 r. o Funduszu Pracy, Dz. U. Nr 22, poz. 163.

Ustawy z dnia 15 marca 1934 r. o Izbach Lekarskich, Dz. U. Nr 31, poz. 275.

Rozporządzenie Prezydenta Rzeczypospolitej z dnia 7 czerwca 1927 r. o prawie przemysłowem, Dz. U. Nr 53, poz. 468.

${ }^{66}$ Petycja właścicieli. 
Rozporządzenie Prezydenta Rzeczypospolitej z dnia 19 stycznia 1928 r. o organizacji i zakresie działania władz administracji ogólnej, Dz. U. Nr 11, poz. 86.

Rozporządzenie Prezydenta Rzeczypospolitej z dnia 27 października 1933 r. o zniesieniu państwowych urzędów pośrednictwa pracy i opieki na wychodźcami, Dz. U. Nr 84, poz. 621.

Rozporządzenie Prezydenta Rzeczypospolitej z dnia 24 października 1934 r. o połączeniu Funduszu Bezrobocia z Funduszem Pracy, Dz. U. Nr 94, poz. 849.

Rozporządzenia Prezydenta Rzeczypospolitej z dnia 28 grudnia 1934 r. o unormowaniu właściwości władz i trybu postępowania w niektórych działach administracji państwowej, Dz. U. Nr 110, poz. 976.

Rozporządzenie Rady Ministrów z dnia 20 czerwca 1921 r. w przedmiocie rozciągnięcia mocy obowiązującej dekretu z dnia 27 stycznia 1919 r. o organizacji państwowych urzędów pośrednictwa pracy i opieki nad wychodźcami na województwa nowogródzkie, poleskie i wołyńskie oraz na powiaty grodzieński, wołkowyski i białowieski województwa białostockiego, Dz. U. Nr 60, poz. 378.

Rozporządzenia Ministra b. Dzielnicy Pruskiej z 14 października 1921 r. o Państwowych urzędach pośrednictwa pracy, Dz. U. Nr 93, poz. 687.

Rozporządzenie Ministra Pracy i Opieki Społecznej z dnia 12 grudnia 1919 r. w przedmiocie likwidacji Komitetów niesienia pomocy dla bezrobotnych i powołania do życia Powiatowych Komisji Pomocy dla bezrobotnych, Dz. U. z 1920 r. Nr 4, poz. 19.

Rozporządzenie Ministra Pracy i Opieki Społecznej i Ministra b. dzielnicy Pruskiej w przedmiocie wykonania ustawy z dnia 21 października $1921 \mathrm{r}$. o zarobkowym pośrednictwie pracy z dnia 30 stycznia 1922 r., Dz. U. Nr 10, poz. 82.

Rozporządzenie Ministra Pracy i Opieki Społecznej z dnia 12 października 1922 r. w przedmiocie zwrotu kosztów kancelaryjnych przez pracodawców, którzy przyjęli do pracy pracowników, poleconych przez państwowe urzędy pośrednictwa pracy, Dz. U. Nr 92, poz. 866.

Rozporządzenia Ministra Pracy i Opieki Społecznej z dnia 15 lutego 1923 roku w przedmiocie zgłaszania w państwowych urzędach pośrednictwa pracy województwa poznańskiego i pomorskiego zapotrzebowań na pracowników wszelkich kategorji, Dz. U. Nr 18, poz. 123.

Rozporządzenia Ministra Pracy i Opieki Społecznej z dnia 3 marca 1923 r. w przedmiocie zwrotu kosztów kancelaryjnych przez pracodawców, którzy przyjęli do pracy pracowników, poleconych przez Państwowe Urzędy Pośrednictwa Pracy, Dz. U. Nr 28, poz. 176.

Rozporządzenie Ministra Pracy i Opieki Społecznej z dnia 28 listopada 1923 r. w przedmiocie zmian w rozporządzeniu z dnia 30 stycznia 1922 r. do ustawy o zarobkowem pośrednictwie pracy, Dz. U. Nr 126, poz. 1031.

Rozporządzenie Ministra Pracy i Opieki Społecznej z dnia 28 maja 1924 r. w przedmiocie ustalenia kaucji zarobkowych pośredników pracy, Dz. U. Nr 50, poz. 511.

Rozporządzenie wykonawcze Ministra Pracy i Opieki Społecznej z dnia 25 lipca 1924 r. do ustawy z dnia 10 czerwca 1924 r. o społecznym pośrednictwie pracy, Dz. U. Nr 67, poz. 652 z późn. zm.

Rozporządzenie Ministra Pracy i Opieki Społecznej z dnia 31 grudnia 1924 r. w porozumieniu z Ministrem Skarbu, Ministrem Przemysłu i Handlu, Ministrem Rolnictwa i Dóbr Państwowych, Ministrem Kolei i Ministrem Robót Publicznych oraz Ministrem Sprawiedliwości w sprawie obowiązku pracodawców zawiadamiania państwowych urzędów pośrednictwa pracy o każdem wolnem lub nowoobsadzonem miejscu, Dz. U. z 1925 r. Nr 2, poz. 23.

Rozporządzenia Ministra Pracy i Opieki Społecznej z dnia 26 stycznia 1925 r. w sprawie regulaminu dla Państwowych Urzędów Pośrednictwa Pracy, M. P. Nr 25, poz. 95.

Rozporządzenia Ministra Opieki Społecznej z dnia 15 marca 1934 r. o biurach pośrednictwa pracy Funduszu Bezrobocia, Dz. U. Nr 22, poz. 168. 
Rozporządzenie Ministra Opieki Społecznej z dnia 15 marca 1934 r. o ustaleniu terminów zniesienia państwowych urzędów pośrednictwa pracy i opieki nad wychodźcami, Dz. U. Nr 22, poz. 169.

Rozporządzenie Ministra Opieki Społecznej z dnia 26 marca 1935 r. o wykonywaniu przez Fundusz Pracy pośrednictwa pracy, Dz. U. Nr 23, poz. 152.

Instrukcja Ministra Pracy i Opieki Społecznej dnia 18 stycznia 1927 r. w sprawie czynności państwowych urzędów pośrednictwa pracy w zakresie rejestracji i ewidencji wolnych miejsc i poszukujących pracy, M. P. Nr 19, poz. 45.

Regulamin Biura Pośrednictwa Pracy Wileńsko-Nowogrodzkiej Izby Lekarskiej z dnia 25 czerwca 1929 r., Dz. Urz. z 1929 r. Nr 225, [w:] https://polona.pl/item/regulamin-biura-posrednictwa-pracy-wilensko-nowogrodzkiej-izby-lekarskiej,NzE2NDM0NDk/2/\#info:metadata [dostęp: 14.11.2019].

\section{LITERATURA}

BornsteIn-Łychowska Melania: Międzynarodowa Organizacja Pracy. Praca i organizacja, Warszawa: Ministerstwo Pracy i Opieki Społecznej 1928.

FikTus Paweł: Ochrona prawna emigrantów w latach 1918-1927 w II RP, Wroctawskie Studia Erazmiańskie. Zeszyty Studenckie 1 (2008), s. 109-123.

H.Ł.O.W.S.: Państwowe pośrednictwo pracy w Polsce i jego reformy, Praca i Opieka Społeczna 3 (1933), s. 221.

JANKowski Stefan: Nowa organizacja inspekcji pracy, Praca i Opieka Spoleczna 4 (1927), s. 24-33.

KICINGER Anna: Polityka emigracyjna II Rzeczpospolitej, Central European Forum for Migration Research 4 (2005), s. 1-81.

Kozıowski Tomasz: Inspekcja pracy w Polsce w latach 1919-1939. Organizacja i działalność, Warszawa: Państwowa Inspekcja Pracy 2019.

KwIECIEŃ Sebastian: Polskie prawo gospodarcze okresu międzywojennego, Lublin: Wydawnictwo KUL 2016.

Międzynarodowa Organizacja Pracy, a prawa kobiet, Warszawa [b.w.] 1930.

MLONEK Krystyna: Bezrobocie w Polsce w XX wieku w świetle badań, Warszawa: Krajowy Urząd Pracy 1999.

OKulicz Bronisław: Roboty publiczne w świetle działalności Ministerstwa Opieki Społecznej, Praca i Opieka Spoleczna 3 (1933), s. 216-217.

Pośrednictwo pracy w Polsce, Warszawa: Ministerstwo Pracy i Opieki Społecznej 1921, [w:] http:// bc.radom.pl/dlibra/doccontent?id=25188 [dostęp: 12.11.2019].

Przeniosıo Marek: Problemy społeczne Galicji Zachodniej w początkach II Rzeczypospolitej (wybrane zagadnienia), Studia z Historii Społeczno-Gospodarczej XIX i XX wieku 12 (2013), s. 87-102.

SŁABIŃSKa Elżbieta: Ewolucja działań publicznych służb zatrudnienia w latach 1918-1939 i 1944-1949. Zarys problematyki, Optimum Economic Studies 2 (2019), s. 95-109.

SŁABIŃSKA Elżbieta: Łagodzenie skutków bezrobocia w województwie kieleckim w latach 1918-1939, Kielce: Wydawnictwo Uniwersytetu Humanistyczno-Przyrodniczego Jana Kochanowskiego 2008.

StańCZYK Elżbieta: Środowisko pracy w II Rzeczypospolitej, Acta Universitatis Wratislaviensis. Przeglad Prawa i Administracji 77 (2008), s. 293-311.

Sterling Helena: Międzynarodowa Organizacja Pracy i jej działalność, Warszawa: Księgarnia Robotnicza 1928.

SzAwLESKi Mieczysław: Kwestja emigracji w Polsce, Warszawa: Polskie Towarzystwo Emigracyjne 1927.

Zasztowt-Sukiennicka Halina: Międzynarodowa Organizacja Pracy, Warszawa-Wilno: L. Chomiński 1929. 
INNE

Petycja właścicieli zarobkowych biur pośrednictwa pracy skierowana do Senatu RP, [w:] https:// polona.pl/item/petycja-inc-dnia-10-grudnia-1929-r-zapada-termin-likwidacji-koncesjonowanych biur,NzQwMjc0MzM/0/ [dostęp: 17.11.2019].

Sprawozdanie z działalności biura pośrednictwa pracy od 17 grudnia 1914 roku do 1 lipca 1915 roku, Łódź [b.w.] 1915, [w:] https://polona.pl/item/sprawozdanie-z-dzialalnosci-biura-posrednictwa-pracy-od-17-xii-1914-r-do-1-vii-1915-r,NzQwNzg4MzE/2/\#info:metadata [dostęp: 17.11.2019].

\section{INSTYTUCJE POŚREDNICTWA PRACY - REGULACJE PRAWNE OKRESU MIĘDZYWOJENNEGO W POLSCE}

\section{Streszczenie}

Stan bezrobocia w Polsce okresu międzywojennego był jednym z największych problemów społeczno-gospodarczych z jakim musiał zmierzyć się każdorazowy rząd. Odbudowa państwa Polskiego, kryzysy ekonomiczne, tak wewnętrzne jak i światowe, odciskały swe piętno na rynku pracy.

Państwo powołując już w roku 1919 państwowe urzędy pośrednictwa pracy, postanowiło w sposób władczy zaingerować w tę sferę polityki społecznej i pozytywnie wpłynąć na sytuację na rynku pracy. Przejęło na siebie tym samym odpowiedzialność za pomoc bezrobotnym. Dominowało przeświadczenie, że tylko należycie zorganizowane państwowe instytucje pośrednictwa pracy to najskuteczniejszy i bezpośredni środek walki z wysokim bezrobociem, które było stałym zjawiskiem ówczesnych czasów. Jednocześnie dopuszczono społeczne i prywatne przedsiębiorstwa pośrednictwa pracy, które miały uzupełnić instrumenty państwowego pośrednictwa pracy i pomocy bezrobotnym. Te jednak działały w oparciu o restrykcyjne zasady i w oparciu o ścisłą reglamentację, co do ilości osób mogących podjąć taką działalność.

Jakkolwiek, nie można zaprzeczyć, że w ciągu 5 lat stworzono zwarty system pośrednictwa pracy, oparty na państwowych urzędach, wspomaganych przez system społecznego i zarobkowego pośrednictwa pracy. Jest to o tyle istotne, że nie było to zadanie łatwe, a oczekiwania społeczne, chyba nie mogły sprostać faktycznym możliwością ich działania.

Słowa kluczowe: państwowe pośrednictwo pracy; bezrobocie; pomoc bezrobotnym; polityka socjalna

\section{EMPLOYMENT AGENCIES \\ - LEGAL REGULATIONS OF THE INTERWAR PERIOD IN POLAND}

\section{Sum mary}

The state of unemployment in Poland in the interwar period was one of the biggest socio-economic problems that every government had to face. The rebuilding of the Polish state, economic crises, both internal and global, have left their mark on the labor market.

By setting up state employment agencies in 1919, the state decided in imperial order to intervene in this sphere of social policy and positively influence the situation on the labor market. It took on the same responsibility for helping the unemployed. The prevailing conviction was that only wellorganized state employment agencies are the most effective and direct means of combating high unemployment, which was a constant phenomenon of the times. At the same time, social and private employment agencies were allowed to supplement the instruments of state employment and help the 
unemployed. These, however, acted on the basis of restrictive rules and based on strict regulation, as to the number of people who could undertake such activities.

However, it can not be denied that within 5 years a cohesive system of job placement was created, based on state offices, supported by a system of social and gainful job placement. This is important because it was not an easy task, and social expectations probably could not cope with the actual possibility of their operation.

Key words: state employment agency; unemployment; help for the unemployed; social policy 